\title{
STRENGTH ANALYSIS OF A GANTRY CRANE OF A COATING STRUCTURE
}

\begin{abstract}
SUMMARY
Gantry cranes with coating construction are used in Polish steel industry much less than truss bridges. For several bridges, which span and the supports have coating construction, there were made series of non-destructive testing, which revealed the presence of numerous fatigue cracks: in the area of a beam pad, the coating, as well as other elements of their supporting structure. Periodically carried out repairs and strengthening of bridges have not eliminated the problem of the emergence of more fatigue cracks. The analysis of FEM, verified by extensometer measurements of strains, gave the basis to designate the most strenuous areas of the construction. Gathered results of periodic non-destructive testing, combined with obtained results of FEM analysis, were the basis for designing appropriate reinforcements and indication the scope of conducting non-destructive testing of considered construction of bridges with coating.
\end{abstract}

Keywords: metal structures, state of stress, FEM, strain measurements, NDT examination

\section{ANALIZA WYTRZYMAŁOŚCIOWA SUWNICY BRAMOWEJ O KONSTRUKCJI POWŁOKOWEJ}

Suwnice bramowe o konstrukcji powłokowej stosowane sa w polskim przemyśle hutniczym znacznie rzadziej od mostów kratowych lub blachownicowych. Dla kilku mostów, dla których przęsto oraz podpory maja konstrukcje powłokową, wykonano serie badań nieniszczacych. Ujawnity one występowanie licznych pęknięć zmęczeniowych: w obszarze belki podszynowej, powłoki, jak również innych elementów ich konstrukcji nośnej. Wykonywane okresowo naprawy $i$ wzmocnienia mostów nie wyeliminowały problemu powstawania kolejnych pęknięć o charakterze zmęczeniowym. Wykonana analiza MES, zweryfikowana pomiarami tensometrycznymi odksztatceń, dała podstawę do wytypowania najbardziej wytężonych obszarów konstrukcji. Zebrane wyniki prowadzonych okresowo badań nieniszczacych, w połaczeniu z uzyskanymi wynikami analizy MES, stanowity podstawe do zaprojektowania odpowiednich wzmocnień oraz rozpisania zakresu prowadzenia badań nieniszczących rozważanej konstrukcji mostów powłokowych.

Stowa kluczowe: konstrukcje metalowe, stan naprężenia, MES, pomiary tensometryczne, badania nieniszczace

\section{INTRODUCTION}

The development of gantry cranes of a coating structure, as an evolution of steel box-structure cranes, started in the fifties of the previous century. Such gantries are characterised by a high rigidity and slenderness, while their drawback constitutes much smaller lifting capacity than the cranes of truss structures of similar dimensions as well as an increased susceptibility to mechanical vibrations. Considerations were performed for three scoop gantry cranes of a lifting capacity of $350 \mathrm{kN}$, operating in one of the Polish steelworks. The bearing element for these cranes constituted the span, $133 \mathrm{~m}$ long, of the coating structure, made of steel plates strengthened by axial and transverse ribbing (Fig. 1).

\section{NONDESTRUCTIVE BRIDGE TESTS}

Complex non-destructive investigations of gantry cranes were performed due to finding in them fatigue cracks after

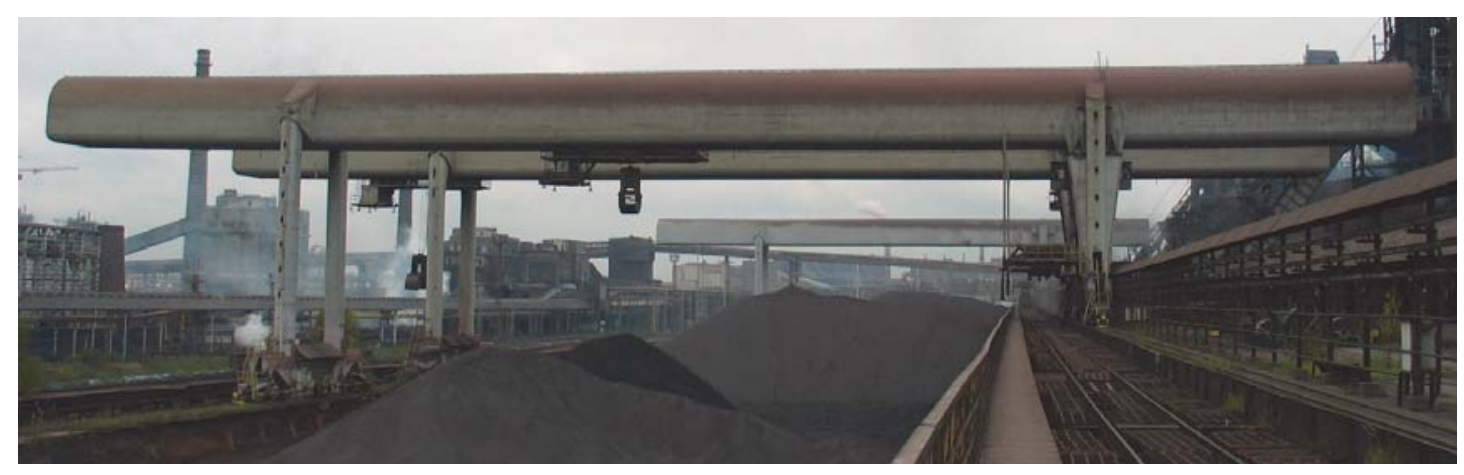

Fig. 1. Gantry cranes of a coating structure

\footnotetext{
* AGH University of Science and Technology, Krakow, Poland
} 
several immediate repairs (Ladecki at al. 2005, 2009, 2010). These examinations contained visual tests of all outside surfaces in order to estimate areas of inadmissible defects of the bearing structure, such as: tears, cracks, permanent deformations etc. They also contained defectoscopic examinations, estimations of corrosion decrements progressing with an ultrasound technique application, analysis of span permanent deformations on the basis of cyclic geodesic measurements of the vertical profile shape of the beam truck crane pad (Ladecki at al. 2010).

The performed non-destructive tests revealed several areas of crack occurrence (the most often of a fatigue character) and other damages of crane structures. The most intensive occurrence of fatigue cracks was found for the beam truck crane pad, for which identified types of damages are illustrated in Figures 2, 3 and 4.

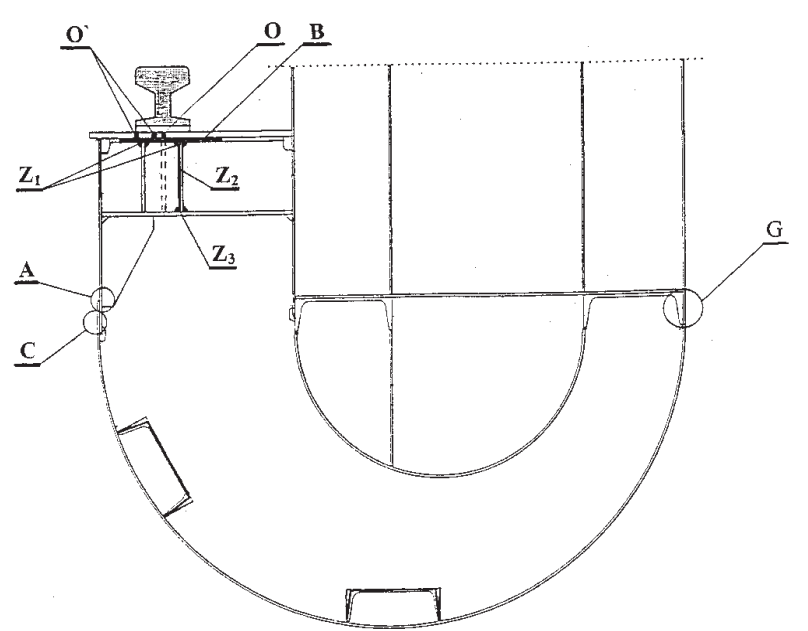

Fig. 2. Location of the detected cracks of the crane beam

Revealed cracks:

Type „A" - welded joint crack, in the lower part of the transverse rib of the crane beam,

Type „B” - crack of the overhead weld joining the upper double-tee bar with the horizontal crane beam plate,

Type „C" - vertical crack of the welded joint of a crane beam plate and coating, located in between ribs of the crane beam,

Type „O” - plate crack under the rail in the direction of the rail axis, close to a rib,

Type „O'” - plate crack under the rail parallel to the rail axis,

Type , $Z_{1}$ ”(,,$\left.Z_{3} ”\right)$ - crack of the joint parallel to the rail axis, rib of the transverse frame rib or frame,

Type , $\mathrm{Z}_{2}$ ”- vertical joint crack, rib of the transverse frame rib or frame,

Type „G” - welded joint crack.

Apart from sporadically detected cracks of type „A”, „C" and „G", for various examination series, it was found that there are: $42-47 \%$ type ,Z” cracks, 13-42\% type „O” cracks and $8-25 \%$ type „B” cracks, in the total number of detected cracks.

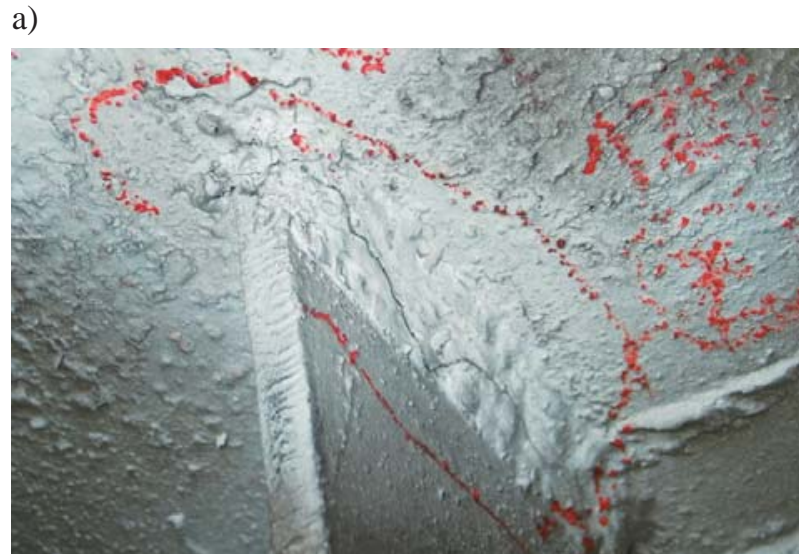

b)

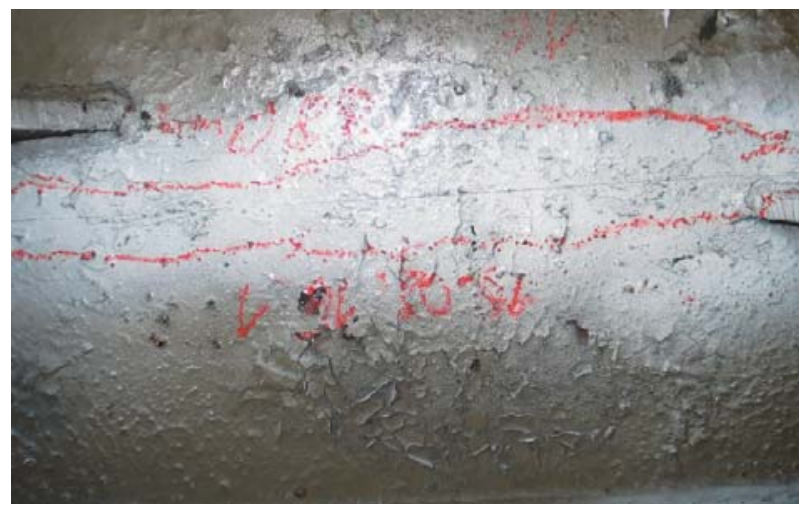

Fig. 3. Cracks of the crane beam revealed by means of the magnetic-powder method: a) type , $Z_{1}$ " joint $120 \mathrm{~mm}$ long; b) type "O”" plate under the rail, $380 \mathrm{~mm}$ long

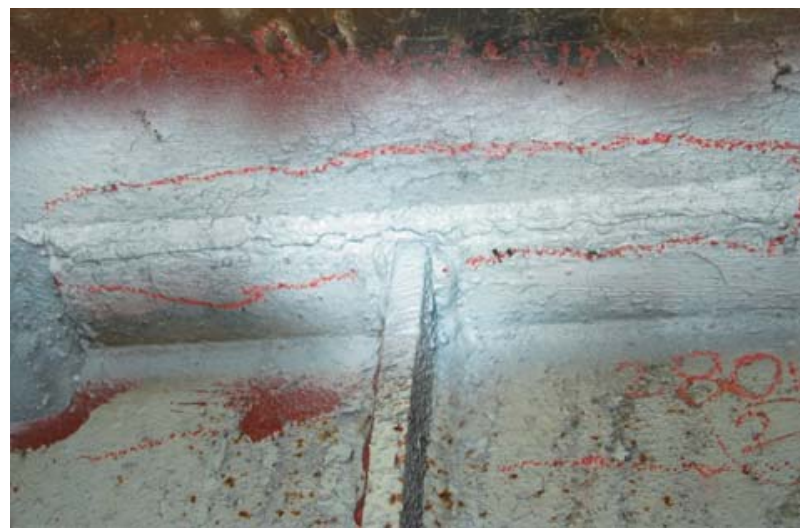

Fig. 4. Fillet weld crack of the crane beam type „B” $240 \mathrm{~mm}$ long, detected by the magnetic-powder method

The occurrence of fatigue cracks were also detected in other areas of cranes, out of which the most dangerous were found near the long support (Fig. 5), and in the short support tube buffet (Fig. 6).

Apart from the discussed above fatigue effects in the exploitation of the cranes the maintenance in good condition of truck railways, where troubles are related to loosening and cracking of screws and periodical cracking of rails, is also a serious problem. 


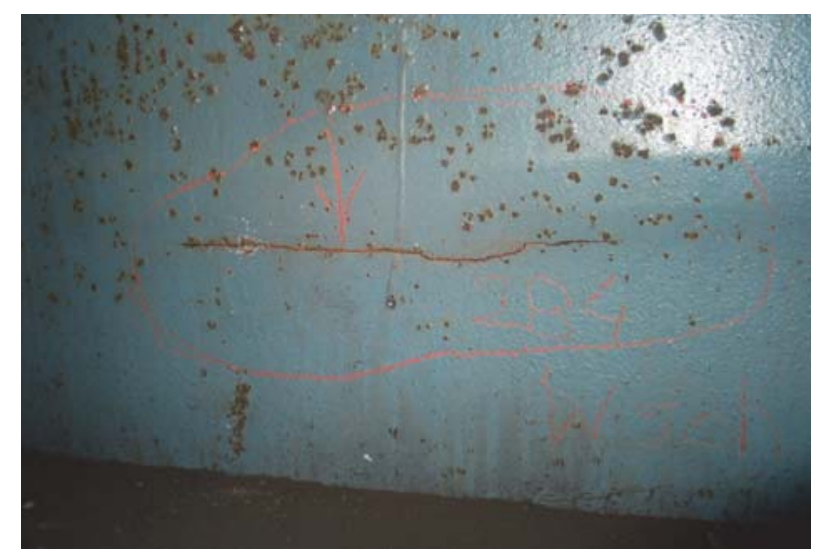

Fig. 5. Coating crack $-284 \mathrm{~mm}$ long - above the long support

In order to explain the existing situation the proper strength analysis, FEM, was performed and verified by extensometric measurements of deformations.

\section{STRENGTH ANALYSIS}

Altogether 17 cases of loading was considered for the developed discrete model of the crane structure (Matachows-

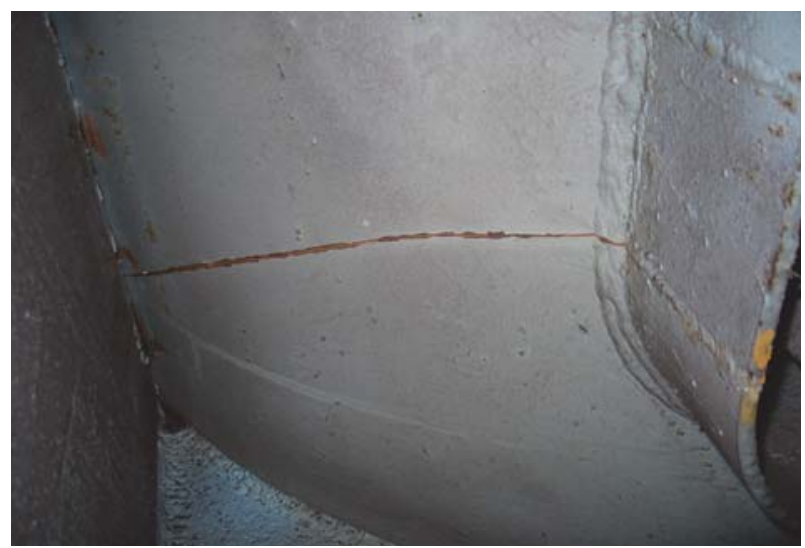

Fig. 6. Crack of the short support tube buffet - at app. 1/3 of a perimeter

ki 2004). The FEM analyses revealed that for the most disadvantageous conditions of structure loading the extreme shearing forces for the span occur in the support areas, while the extreme bending moment values in the support areas and in the middle of the span length between supports (Fig. 7). These areas are compatible with the areas of the highest intensity of fatigue cracks in crane beams.

Examples of the results of the reduced stresses obtained in accordance with the Huber - Misses hypothesis - for the

a)

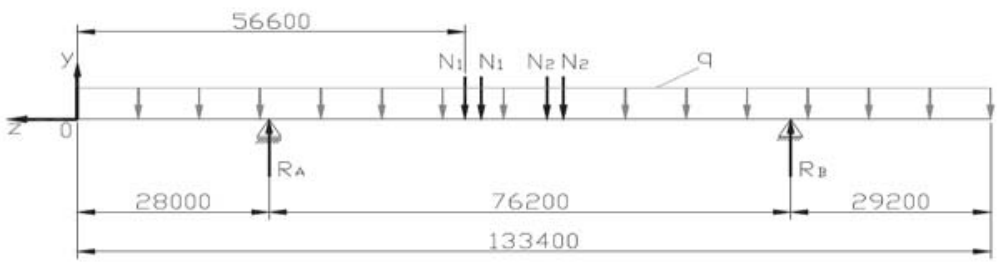

b)

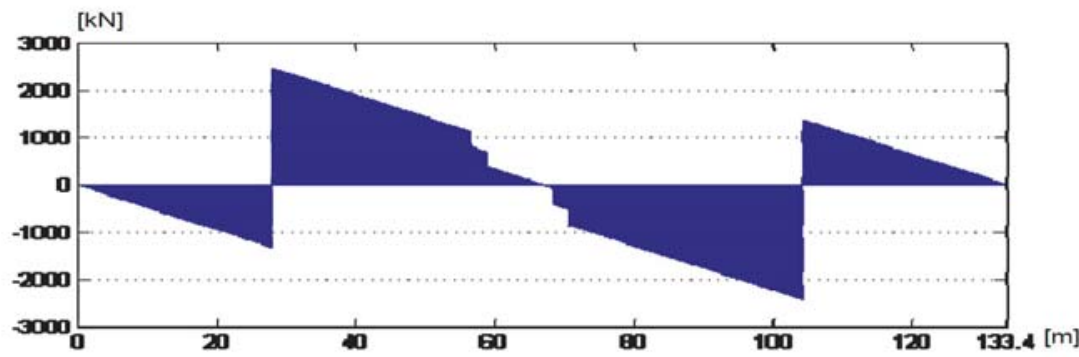

c)

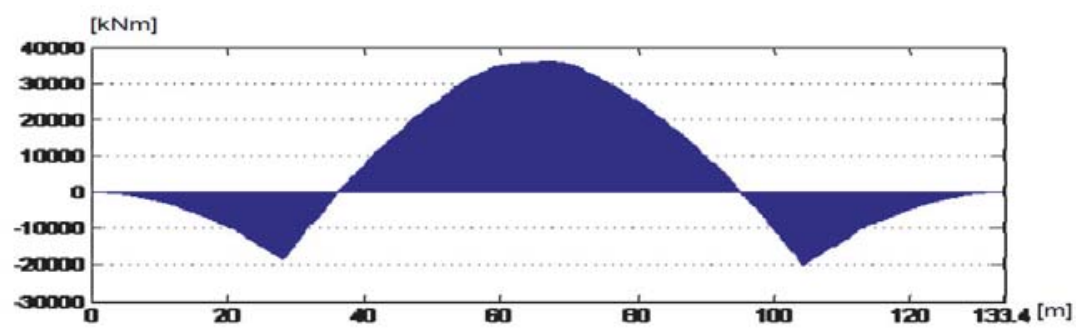

Fig. 7. FEM analysis - load variant 2: a) beam model for the truck position $56.6 \mathrm{~m}$; b) diagram of shearing forces; c) diagram of bending moments 
span and crane beam, for one of the loading variants are presented in Figures 8 and 9. The selected FEM results for the crane beam elements are listed in Table 1. Extreme val- ues of the reduced stresses for the crane beams being equal $65 \mathrm{MPa}$, were obtained for the area of the cracks of the fillet joints of type „B” and ,Z”.

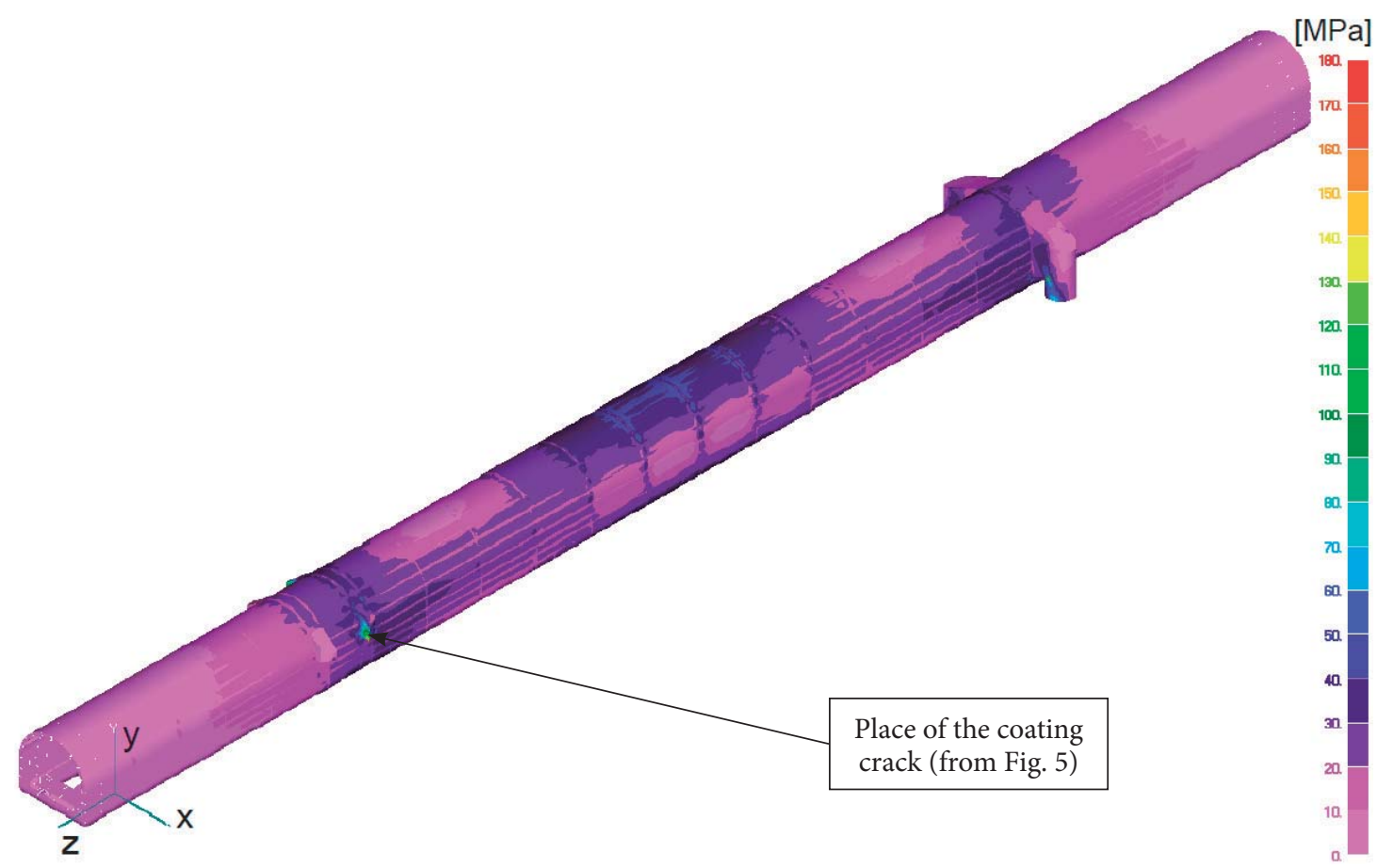

Fig. 8. FEM analysis - distribution of the reduced stresses in the span - load variant 2
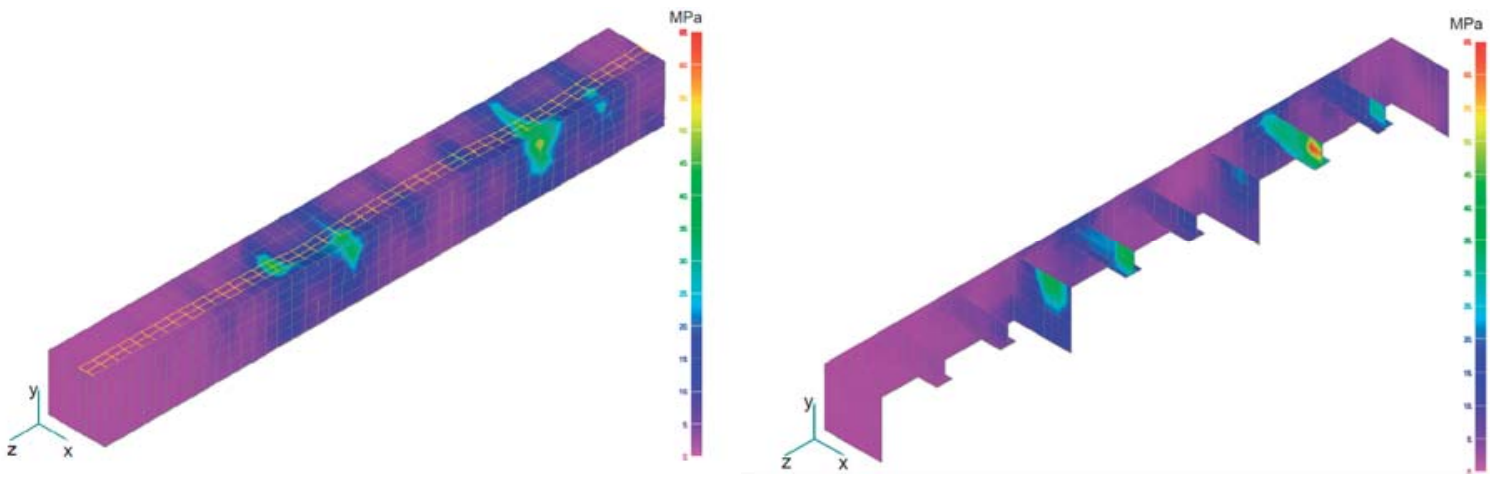

Fig. 9. Distribution of the reduced stresses in the crane beam - load variant 2

Table 1

Selected FEM results for crane beam elements

\begin{tabular}{|c|c|c|c|}
\hline \multirow{3}{*}{ Crane beam element } & \multicolumn{3}{|c|}{ Stresses $[\mathrm{MPa}]$} \\
\hline & \multicolumn{2}{|c|}{ Reduced stresses for the loading variant: } & \multirow{2}{*}{$\begin{array}{l}\text { Fatigue category } \\
(\text { PN-90/B-03200) }\end{array}$} \\
\hline & $\begin{array}{c}1-\text { Truck on the short } \\
\text { support }\end{array}$ & $\begin{array}{c}2-\text { Truck in the middle } \\
\text { of the span }\end{array}$ & \\
\hline Side strips & 60 & 53 & 160 \\
\hline Membranes & 65 & 65 & 100 \\
\hline Cracks type „B” \& ,Z” & 65 & 57 & 57 \\
\hline
\end{tabular}




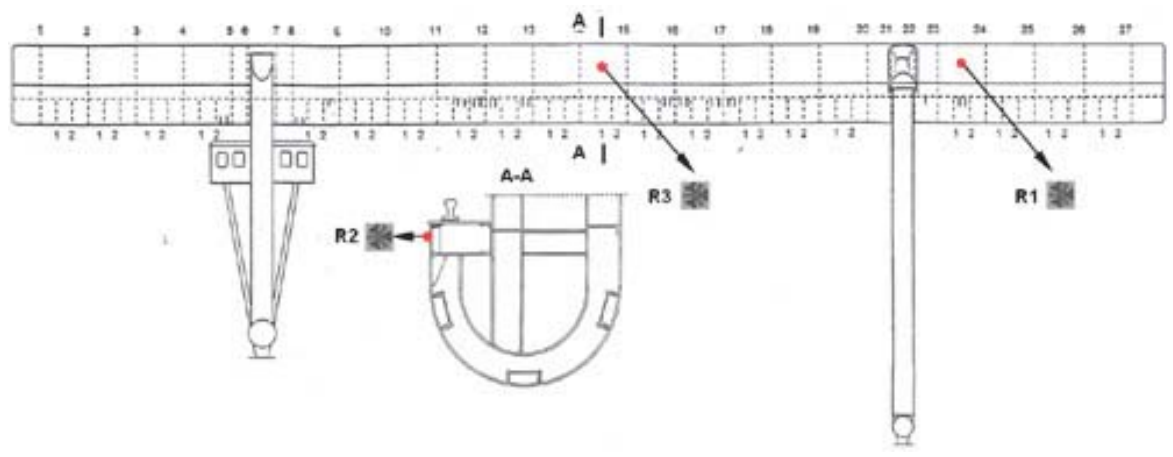

Fig. 10. Arrangement of the measuring sensors

\section{EXPERIMENTAL PART}

In order to verify the obtained FEM analysis results the extensometric measurements of deformations were carried out. These measurements were made for two work cycles of the bridge (Badura at al. 2009, Ładecki at al. 2010). The first cycle comprised driving: of an empty truck, of a fully loaded truck and after its unloading at the arrested bridge. The second cycle comprised of driving of the whole bridge with an empty truck parked on the short support. Three strain gauge rosettes marked R1, R2, R3 type TFxy-4/120 were used in measurements, and measurements were carried out after zeroing the instrument at the work cycle beginning. The location of the measuring sensors placed at the western side of the bridge between frames No. 14 and 15 within the crane beam area and on the coating behind the bridge long support are illustrated in Figure 10.

Examples of the results of the reduced stresses obtained in accordance with the Huber-Misses hypothesis - for the span and crane beam, for one of the loading variants are presented in Figures 8 and 9. The selected FEM results for the crane beam elements are listed in Table 1. Extreme values of the reduced stresses for the crane beams being equal $65 \mathrm{MPa}$, were obtained for the area where the cracks of the fillet joints type „B” and „Z” occur.

The highest values of reduced stresses recorded in the work cycle 1 and bridge cycle 2 listed together with the FEM analysis results (corresponding to cycle 1) are shown in Table 2.
Table 2

Results of extensometric measurements

\begin{tabular}{|c|c|c|c|}
\hline \multirow{2}{*}{$\begin{array}{c}\text { Sensor } \\
\text { No. }\end{array}$} & \multicolumn{3}{|c|}{ Reduced stresses $\sigma_{\mathrm{z}}[\mathrm{MPa}]$} \\
\cline { 2 - 4 } & Cycle 1 & Cycle 2 & MES - cycle 1 \\
\hline R1 & 18 & 3,5 & 17 \\
\hline R2 & 20,5 & 1 & 18 \\
\hline R3 & 16,5 & 4,5 & 20 \\
\hline
\end{tabular}

Examples of diagrams of stresses variability recorded by rosette R2: for the work cycle 1 is shown in Figures 11a, while for driving of the whole crane (cycle 2) in Figures $11 \mathrm{~b}$. Results shown in Table 2 indicate good compatibility of the calculation results and measurements.

\section{CONCLUSIONS}

Non-destructive investigations of cranes indicated an occurrence of several fatigue cracks, which sources were not eliminated at immediate repairs.

On the basis of the FEM analysis, verified by extensometric measurements of deformations, the most endangered areas of crane structure, corresponding to places of the fatigue cracks occurrence were determined. Extreme values of the reduced stresses for crane beams of $65 \mathrm{MPa}$, were obtained for the occurrence areas of the fillet joints

b)

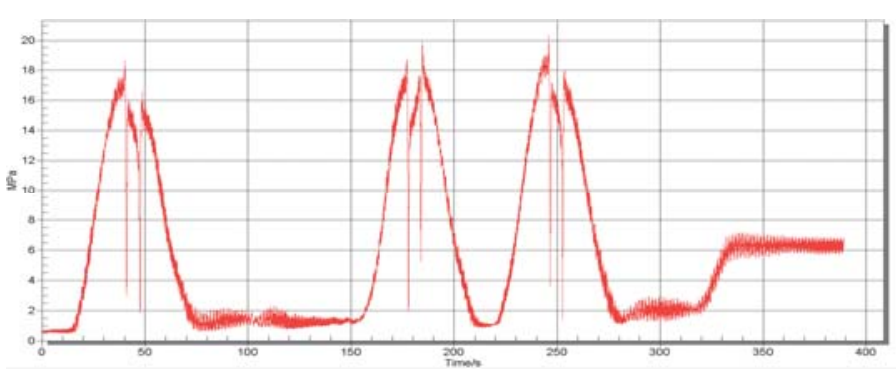

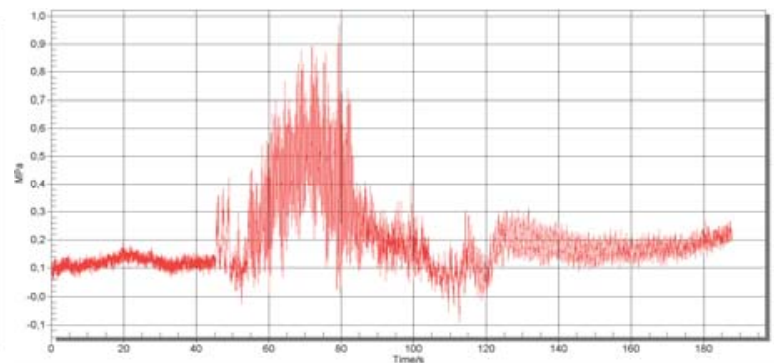

Fig. 11. Diagram of variability of reduced stresses: a) at crane work cycle 1 - rosette R2; b) at cycle 2 of the crane driving - rosette R2 
cracks type „B” and „Z”, while the source of often detected cracks of type „O” is probably their vicinity to cracks of type „B” and „Z”, from which type „O” cracks the most often were developing.

The exploitation history of the discussed objects is not known, however when taking into consideration the fatigue category, for the crack occurrence area, determined as $57 \mathrm{MPa}$ (PN-90/B-03200), exceeding of the fatigue strength of the welded joints can be indicated as the reason of forming and progressing the fatigue cracks. The presented calculations and measurements can be used for more accurate fatigue strength analysis. They constituted the bases for performing the relevant strengthening of crane structures.

\section{References}

Badura S., Ładecki B. 2009, Pomiary odksztatceń mostu powłokowego, AGH, KWZMiK, Kraków (unpublished).

Ładecki B., Badura S., Matachowski F. 2010, Analiza eksperymentalna mostu przeładunkowego o konstrukcji powłokowej, XXIV Sympozjum Mechaniki Eksperymentalnej Ciała Stałego. Wrocław.

Ładecki B., Borowiec W. 2010, Monitoring geodezyjny jako nieniszczaca metoda oceny stanu technicznego konstrukcji, 39 KKBN, Szczyrk.

Ładecki B. et al 2003, 2005, Ekspertyza techniczna mostów powłokowych Oddziału Wsadu Wielkich Pieców, PREH Sp. z o.o.

Ładecki B. et al. 2009, 2010, Ekspertyza mostów przeladunkowych w Zakładzie Wielkie Piece. PREH Sp. z o.o.

Matachowski F. 2004, Analiza wytrzymałościowa powłokowego mostu przeładunkowego, AGH, KWMiK, Kraków, MS Thesis.

PN-90/B-03200 Konstrukcje stalowe. Obliczenia i projektowanie. 